\title{
Fortress churches on the Spanish Mediterranean coast in the sixteenth century
}

\author{
A. Palenzuela Navarro \\ University of Castilla-La Mancha, Spain
}

\begin{abstract}
This paper analyses the role of the churches within the defense systems designed in the early modern period along the Spanish Mediterranean coast. The defensive systems include these churches, which are built as a consequence of the turbulent military conflicts between southern and northern Mediterranean countries during the time period running between the Middle Ages and the 17th century. These type of churches can be defined as fortress churches, and are described as elements of defensive architecture used to protect the population and to prevent and control from future attacks.

The fortress church is a typology that stands out within the defensive constructions that are built on both shores of the Mediterranean Sea. These fortress churches share similar morphological and functional characteristics as well as common elements, establishing a new dual typology between the religious and the military. These churches are integrated into the defensive network as a key piece of it.

This construction is linked to the Mediterranean coast of Western Europe, and its emergence will coincide with the rise and expansion of the Ottoman Empire, piracy and corsairs during the 15th and 16th centuries. In that period, elements of military architecture are added to existing churches, but later on, this approach will evolve into the construction of purely defensive buildings where the religious architectural elements are relegated to the background.

Keywords: church fortress, defense system, typology, Mediterranean coast, military architecture.
\end{abstract}

\section{Introduction}

The history of piracy in the Mediterranean Sea begins many centuries ago, at the end of the Middle Ages, where maritime traffic routes were open, running north 
to south, from the Christian kingdoms like Aragon to territories from Al-Andalus and North Africa. A traffic that would promote economic activity and exchanges on both sides of the Mediterranean, independently of the religion professed.

However, although piracy was lawful it will be punished later by Pope Nicholas IV, in 1291, by excommunication, becoming since then a criminal activity. Even having this new legal framework, the sea lanes continue with apparent normality, because of the good relationship between King Pedro of Aragon and the Moorish Kingdoms, as shown in the conquest of Sicily by Aragon. We will soon see the first actions of piracy around the Strait of Gibraltar.

It is from 1500 when the Berber-Turkish incursions occur. These pirates who attacked the Mediterranean stocks, especially the south-east Mediterranean, the Iberian Peninsula, the Balearic Islands, Sardinia, Corsica, Sicily and the Italian peninsula, were normally from North Africa. They are so called the Berber pirates. With the conquest of America, it is when the coasts of the Spanish kingdom suffer the greatest piratic invasions, because of the kingdom had to ample territorial domain and it had to maintain the empire. Most pirate attacks come from Algiers and Oran, and the populations Cullera, Oropesa, Vinaroz, Mahon, Denia and Alicante were the hardest hit in the first instance [1].

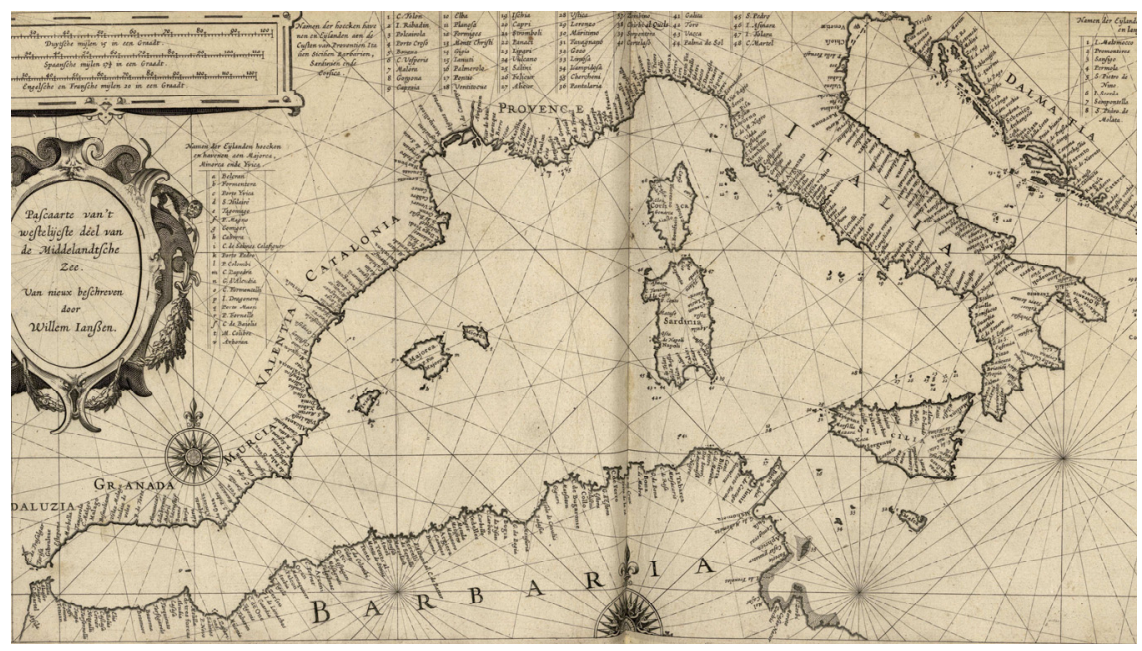

Figure 1: $\quad$ Map Medt aleman Blaeu, 1618.

It will be the moment of the landings of pirates in Cullera (1503) and Denia (1518) or in Teulada [2], activities that will be happening too in those years in other coastal towns, accompanied by the presence of Muslim majority in the inland valleys near waterfront, as is the case of the Alpujarras in the Kingdom of Granada, or the valleys of Ricote in Murcia and inland valleys of the Kingdom of Valencia.

Algerian squads attack Cullera (1532) and Villajoyosa (1536). It is a paradigm of the attacks that carried out repeatedly in the various populations of 
the Spanish Mediterranean. However, the general trend in the 16th century and part of the next two centuries is the partnerships created between African and Turkish pirates, synchronously attacking the Spanish Mediterranean coast, especially the populations that had a defensive system inherited from the Middle Ages.

Faced with this persistent situation of continuous raids and attacks on the Mediterranean coast of the Spanish crown by Barbary pirates and other corsairs, the fortified church emerge like a new dual typology, between the religious and military, which inserted in a defense system that delimit borders, commerce and religion with antagonistic interests. Similar constructions will appear in the different kingdoms along the Mediterranean coast, and their function will be maritime defense like a fortified church.

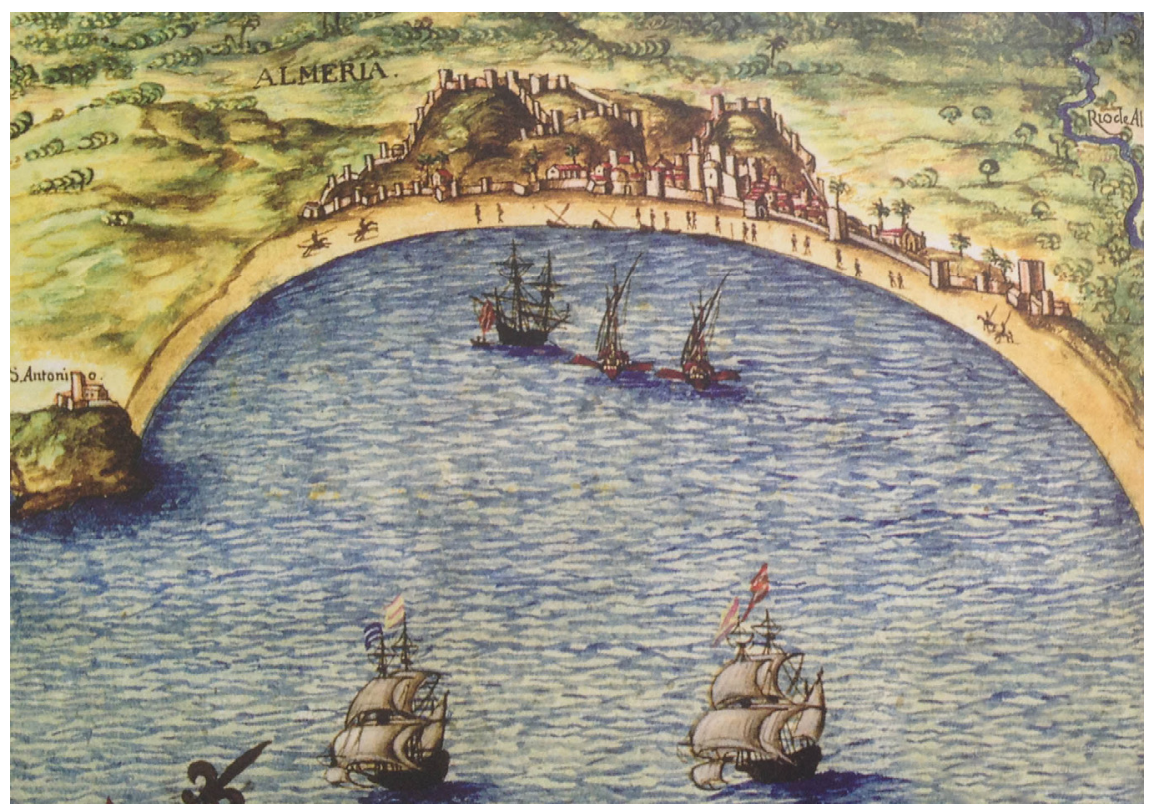

Figure 2: $\quad$ Port of Almería by Pedro de Texeira, 1634.

\section{The church fortress in the Mediterranean coast defensive system}

This heritage is born among military clashes between south and north of the Mediterranean Sea from the Middle Ages to the 17th century, where they arise as defensive architecture that will serve to protect the population, control and prevent future attacks. Among the defensive constructions that are built on both sides of the Mediterranean, there is a typology which will stand out and it will maintain a similar morphological and functional characteristics. The fortified church is the typology that to be bonded in a defensive chain as a link of it. 
This construction that will be closely linked to the Mediterranean coast of Western Europe, and its appearance will coincide with the beginning, apogee and expansion of the Ottoman Empire and the new political relationship of the European states with the Corsican during the 14th, 15th and 16th century.

At first the defensive churches incorporates elements of military architecture rather than religious architecture, like towers and battlements, but soon will be buildings with a strong defensive sense, where the parameters purely religious are relegated to the background.

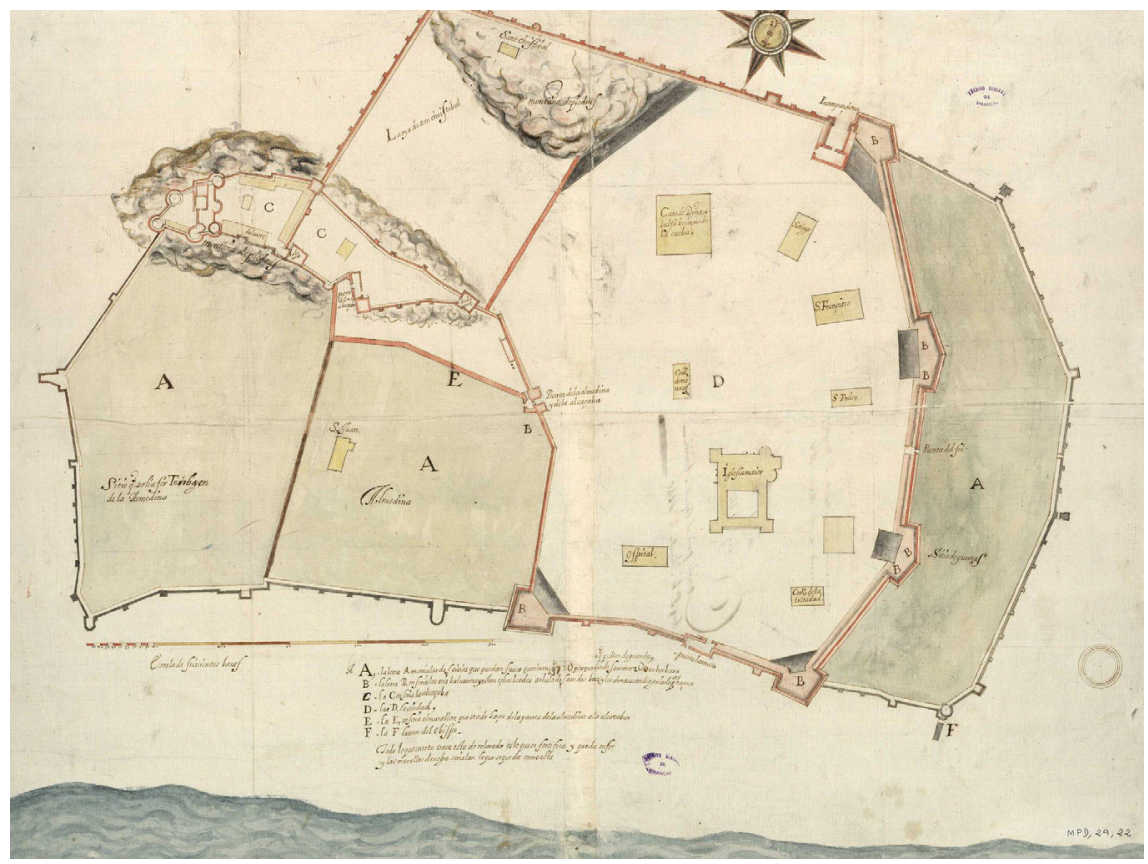

Figure 3: Map of fortification Almería by Juan Oviendo, 1621.

\subsection{Examples of church fortresses on the Spanish Mediterranean coast}

We want to structure this description of the typology based in the geographical location in where it is inserted. On the study conducted, we found three main areas of influence in this defensive architecture that will be developed with similar stylistic and formal characteristics.

Therefore, we structure this classification into three zones:

- The Kingdom of Valencia, whose business activity is mainly played in the Grao de Valencia and Alicante coast. In the coves of the last one will be points of landing of pirate ships in the 15 th century from the Kingdom of Granada [3] and Barbary pirates from Algiers during the 16th century. That zone of land in front the sea will be used by Old Christians to communicate with the interior of Spain through new defense systems like towers and bastions, and new parishes, most of them like churches fortress. 
This phenomenon was reflected especially in the Alicante regions of Marina Alta and Marina Baja, where the succession of valleys and coastal landforms would make it them an ideal place for piratical raids, where have been detected more than ten examples of church fortress, being the highlight St. Bartholomew in Javea, St. Catherine in Teulada and St. Michael Archangel of Murla or Our Lady of the Assumption in Villajoyosa.

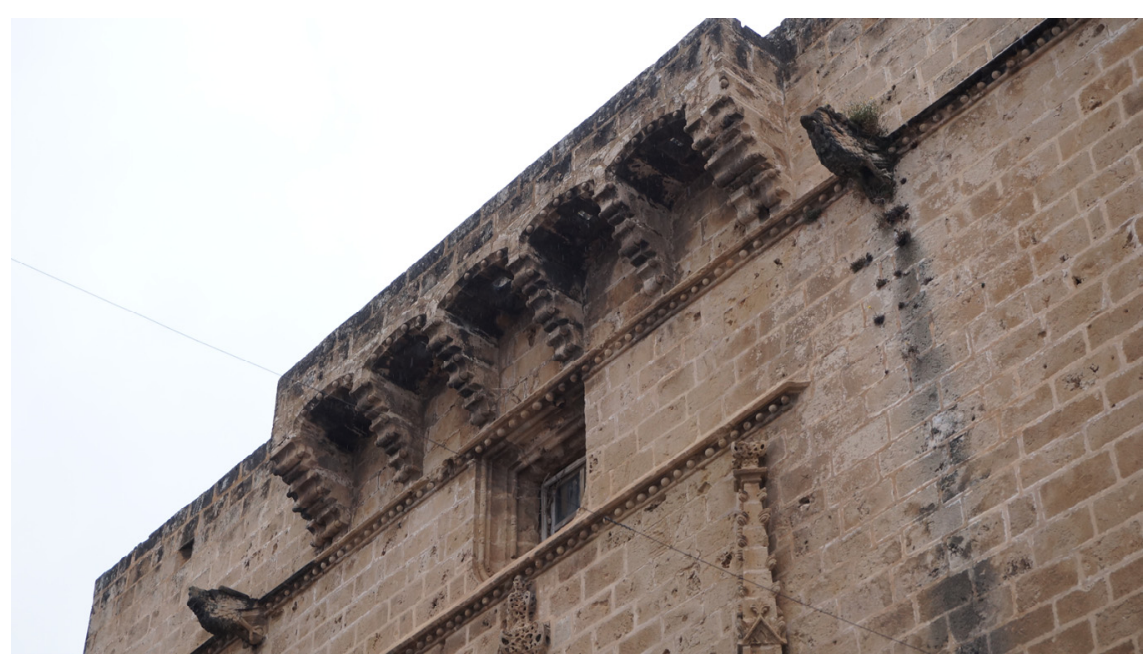

Figure 4: Machicolation detail of the fortress church Saint Bartholomew in Javea.

- In the Balearic Islands, especially in the Pitiusas (Ibiza and Formentera), suffered the continuous attacks of Turks and Berbers along the 16th century. With the arrival of Charles I in 1516 the Christian defenses of North Africa became weaker for not receiving necessary financial resources [4]. This will cause the Turkish-Berber harassment in Formentera and Ibiza. Now this territory will be at the first line of fight. The ship landings will be taking place in Santa Eulalia and Formentera in the years 1535, 1541 and 1543. In this places will be where St. Anthony, St. Michael, St. Eulalia and St. George were founded [5].

- The Kingdom of Granada, where the Christianization of the old Muslim kingdom will be held among other things, like the construction of churches of the Archbishop of Granada in 1501, and in 1505, as well the Diocese of Almería, Málaga and Guadix [6]. In this geographical context of the Almería coast there are three important examples, such as the Church of the Encarnation in Vera, the cathedral of Almería and St. Marie of Mojacar. 


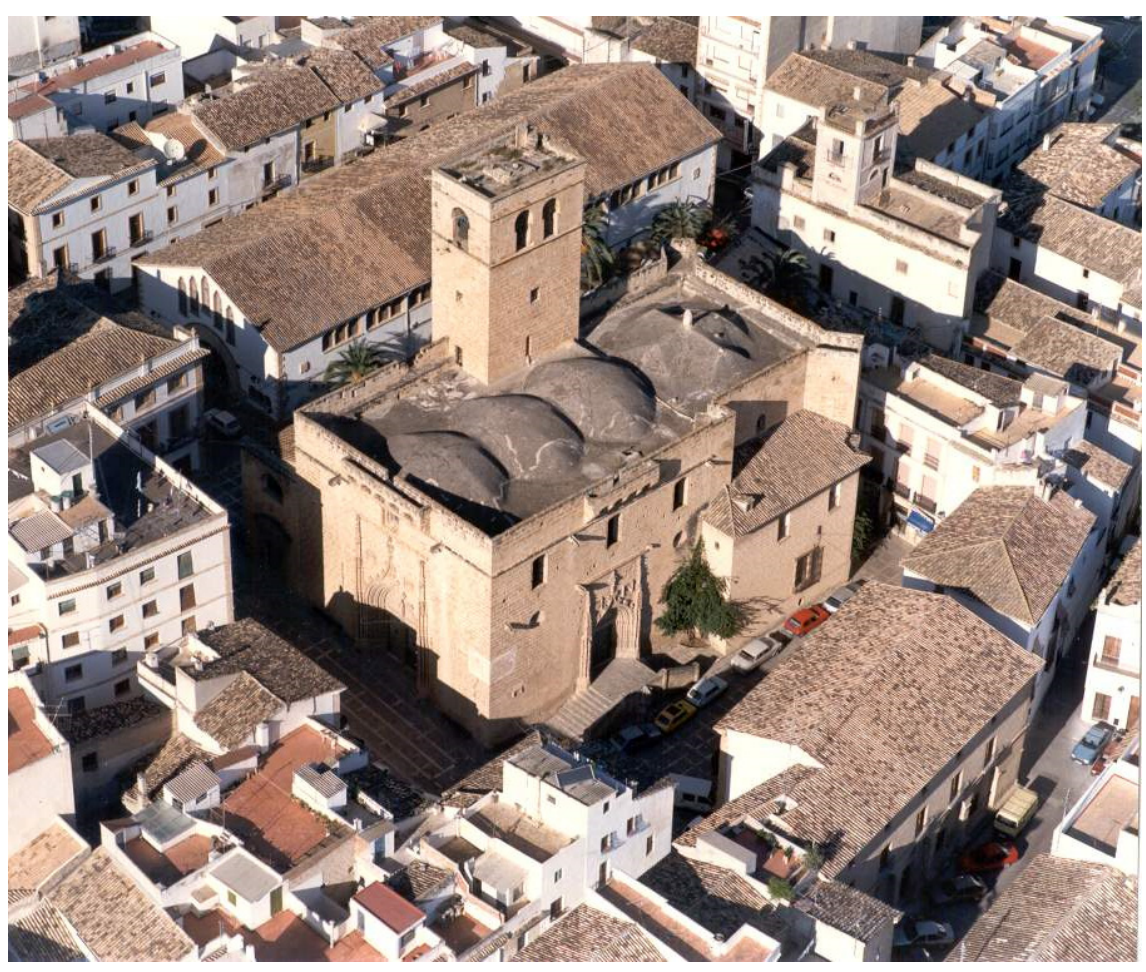

Figure 5: View of the roof of Saint Bartholomew in Javea.

\subsection{Characteristics of the fortress churches}

Based on the cases studied, we can see the following common characteristics:

- $\quad$ They are placed in an arc proximity to the coast of no more than 5-10 km. In this strip of territory other fortified elements are found that will help to build a chain of defensive resistance.

- They inserted one element in a defensive line of constructions like walls, towers and prisons. The defense of the territory was part of a global and regional strategy, so the fortress churches were part of systemic gear of Mediterranean coastal defensive chain.

- They are built in stone ashlar rigging techniques or similar to other purely defensive constructions such as defensive walls or masonry cubes defense. This characteristic is very common among all the examples studied. This is due largely to be the material most commonly prescribed by all treaties of this historical moment, because the whole tradition of poliorcetica and castrametation had been perpetuated.

- Spatially, these churches are composed of one or three naves with heights in the range of 10 to 15 meters, all at the same level on the roof, the halleskirche style, thus showing outside buttresses. It is a space maneuver 
that allowing a flat cover on, and if it would be necessary they could upper a level looking for a better distribution of defensive resources in a battle.

- They have flat roofs, as a terrace, with a stone balustrade that can be crenellated or not, surrounding the entire perimeter of the building. This is an essential part of the structure of the church fortress, and thanks to this architectural formalization, can allow the attack and defense at the same time of their immediate environment and the church itself. Besides, these flat roofs facilitated the movement of troops conducting the defense for move quickly to the different sides of attack, as well as can carry guns, cannonry or other weapons that required a continuous, horizontal surface.

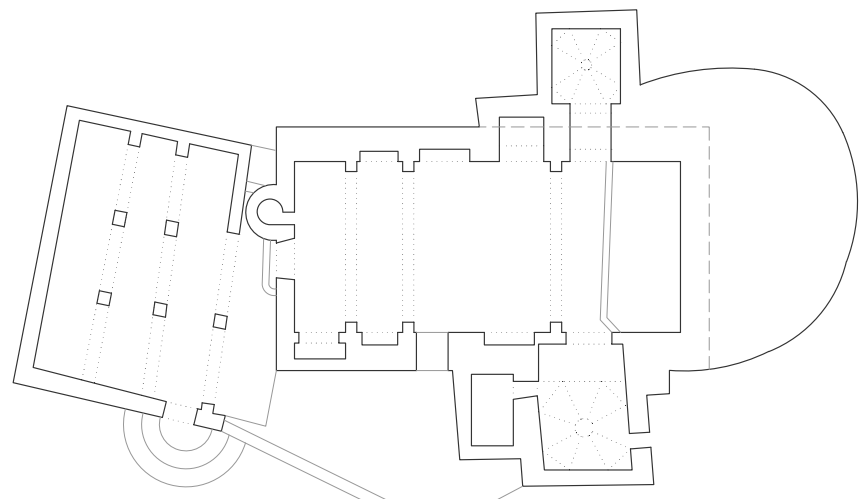

Figure 6: Floor plan of St. Eulalia in Ibiza.

- Usually the naves of these churches develop late Gothic techniques, such as the ribbed vault, but also used in other cases the barrel vault. As a rule, these are the most common techniques due largely to its natural structural strength, and the spread of these techniques developed at a historic moment, around the 15th and 16th centuries, which used to be the techniques most commonly employed at this time.

- Stresses the austerity of its exterior elevations, where the canvas of the walls are naked, stripped of all decoration, where which only appears on the covers. It is a common feature. They have their rationale in its merely defensive nature, where the facades become great walled panels that have to withstand missiles and more missiles. So the decor was confined to specific places and even residual areas from the defensive standpoint. In most cases this ornament was Christian symbolism, and had a strong evangelic message. It was aside, on some of their covers, always in a discreet way, and sometimes with a rather childish and archaic invoice. However, we found exceptions like cathedral fortress Almería, which stands for a few designs made by Juan de Orea. 


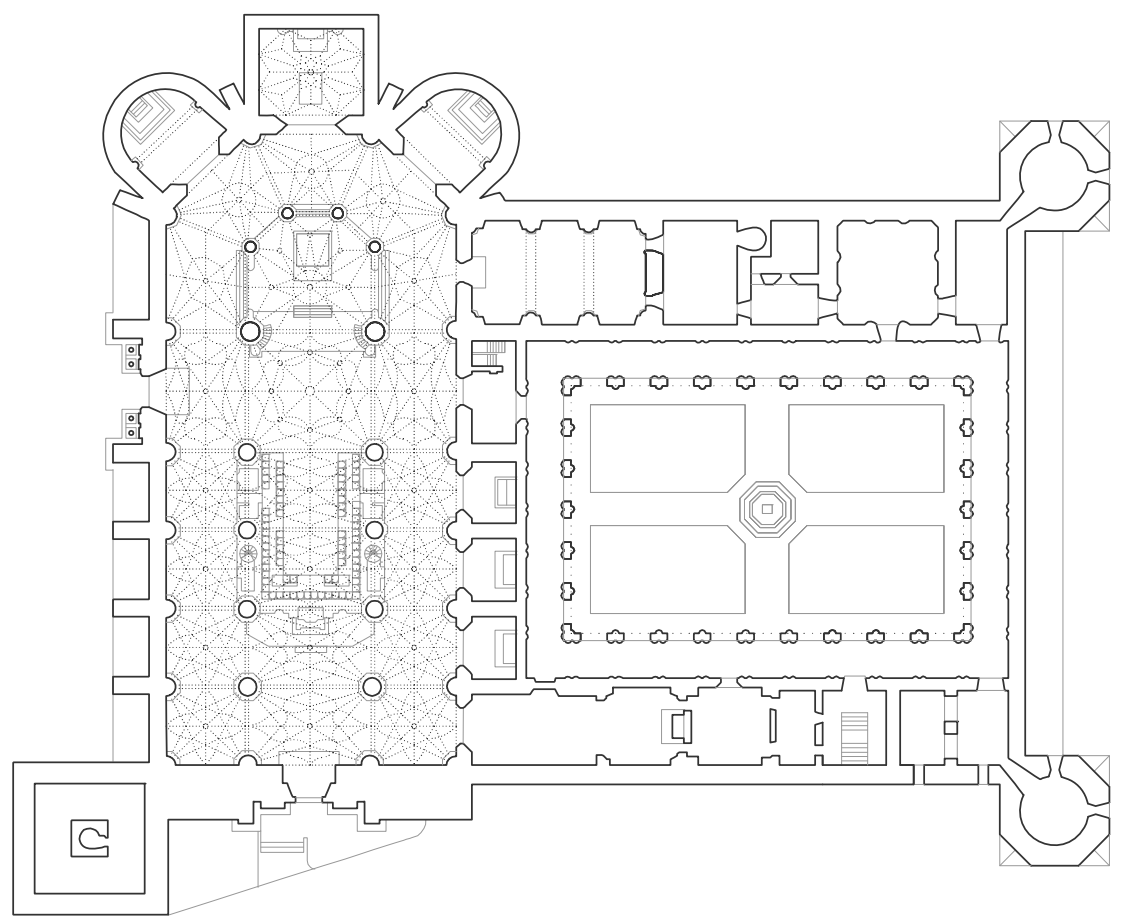

Figure 7: Floor plan of the cathedral in Almería.

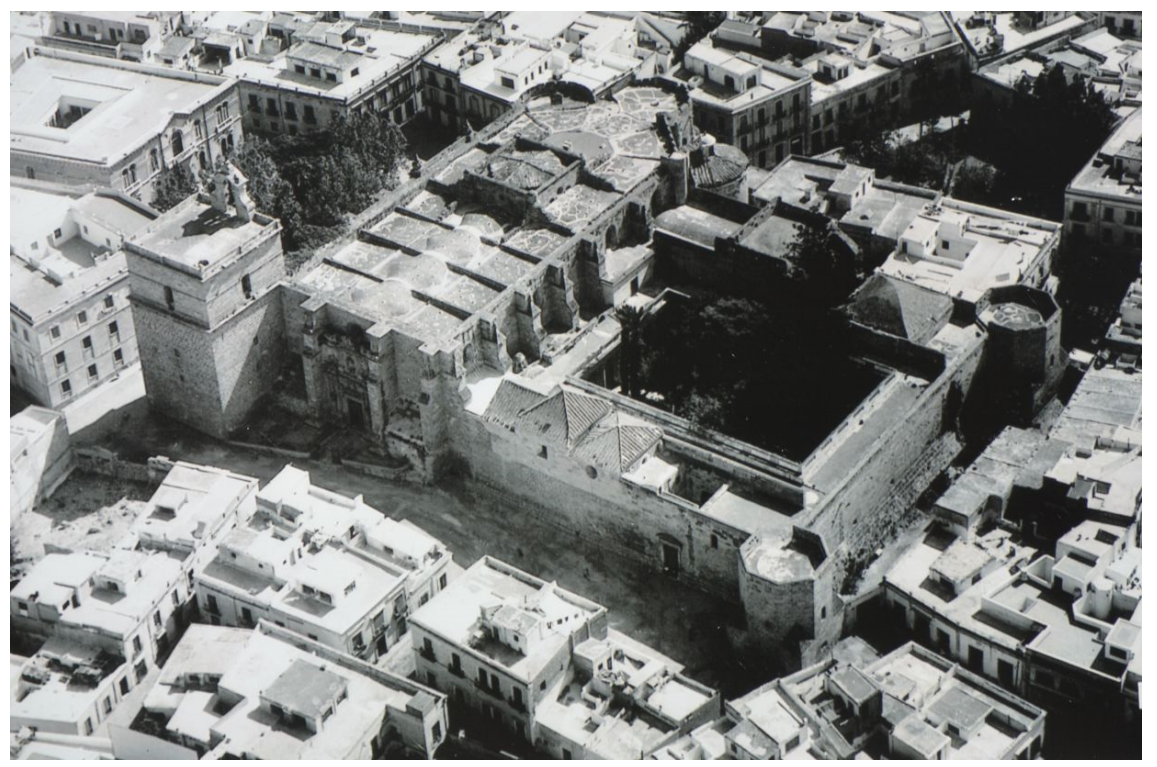

Figure 8: View of the roof of the cathedral in Almería. 
- These churches include defensive towers, which serve as the bastions of medieval castles. Currently, many of the examples that have been preserved until today, have become bell towers after successive renovations in later centuries, with incorporating new bodies in these towers. This has come to distort its original design. They were like lighthouses of a port, from where they communicated with the rest of the defense system and they allowed warn people of impending attacks or landings that would suffer the population.
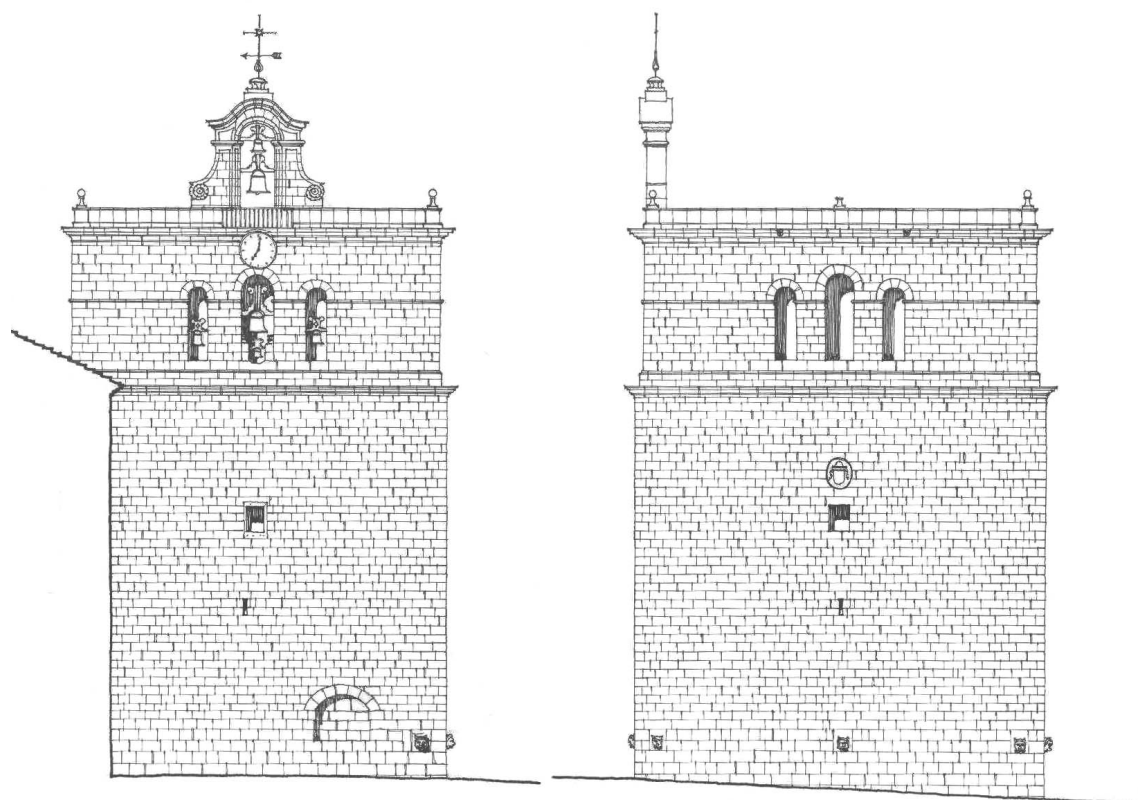

Figure 9: Front and lateral view of the tower of the cathedral in Almería.

\section{Conclusions}

Fortress churches are elements of defensive architecture used to protect the population built during the early modern period. The fortress churches are a typology that is developed in a systematic way during two phases of implementation.

The first phase will take place around the 14th and 15th centuries in the European Western Mediterranean Area. We find examples of these churches on the coast of Provence, the French Roussillon, Italian Liguria and the Balearic Islands. This location makes great sense if we understand that the frontier of the Muslim world was located along the African Maghreb and the Islamic territory in the Iberian Peninsula. 
As the Christian reconquest (the "Reconquista") progresses, and the last Muslim kingdom in Europe, the Nazari Kingdom of Granada, disappear, a new phase develops during the 16th and 17th centuries. At this second phase, the war frontline is located at the border of the Kingdom of Valencia and the Kingdom of Granada. This phase has a more intense territorial expansion, where the fortified church is found at the enclaves further south in Europe.

These churches will also form part of the coastal defense network, incorporated into a common geographic framework at a particular time in history, the 16th century, hence the need to address this research in greater detail in later investigations to understand the process of development and proliferation of that type of structures on the Mediterranean coast.

Regarding future preservation of these churches, we have to consider that the churches are included as part of the defensive architecture network of the Mediterranean coast among different countries, and are composed of different constructions and elements with varied typology. Therefore, it will be necessary to protect the whole Mediterranean defense network system among the countries. In the case of Spain, there is no applicable protective law to coordinate all the autonomous communities or regions.

We would need to proceed to an exercise of assessment and social recognition of this heritage. The practical and functional character of the coastal defense, formalized in the fortress churches with an austere decoration, meant sometimes a shortage of presence of symbolic and ornamental elements, making it difficult the appreciation of their artistic and architectural value, and consequently, the importance of conservation.

In many situations, the duality between the religious and the defense characteristics changes among the time, and one role overcomes the other. Almost as a rule, the religious function is maintained, leaving the military identity in the background, disappearing from historical values.

The fortress churches have historical and artistic characteristics similar to the defensive chain they integrate, and are included in the defensive system on the Mediterranean coast. This defensive coastline of the Mediterranean arc has its peak between the 15th and 17th centuries, and is an architectural heritage that adds to the cultural palimpsest that is the Mediterranean Sea. Greater protection of the Mediterranean coastline will be necessary for a better assessment of this architectural and landscape heritage.

\section{References}

[1] Sancho Pons, E., Moros en la costa, Sociedad Geográfica Española, ${ }^{\circ}$ 18, pp. 30-47, 2004.

[2] Ivars Pérez, J., La vila de Teulada. Procés de fortificació i estructura urbana. Aguaits: Revista d'investigació $i$ assaig, Ed. Institut d'Estudis Comarcals de la Marina Alta, nº 1, pp. 49-64, 1988.

[3] Hinojosa Montalvo, J.R., El Reino de Valencia: frontera maritima entre Aragón y Granada. Actas del Congreso la Frontera Oriental Nazarí como 
Sujeto Histórico (S.XIII-XVI): Lorca-Vera, 22 a 24 de noviembre de 1994. Universidad de Alicante, pp. 409-434, 1997.

[4] Serra Rodríguez, J.J., Fortificaciones rurales en la Isla de Ibiza: las torres de refugio prediales, Barcelona. Ed. Escuela Universitaria de Arquitectura Técnica de Valencia. Mediterrania-eivissa, p. 376, 2000.

[5] Mora Piris, P., Tratados y Tratadistas de fortificación. Siglos XVI al XVIII, En Posada Simeón, J.C. Cartografía histórica en la Biblioteca de la Universidad de Sevilla, Sevilla, pp. 120-147, 2010.

[6] Martín García, M., Iglesias fortificadas del Reino de Granada, Huerta, Santiago y Fabián López Ulloa Ed. Actas del Octavo Congreso Nacional de Historia de la Construcción. Madrid, 9-12 de octubre de 2013. Madrid: Instituto Juan de Herrera, pp. 611-620, 2013. 